\title{
Promoting Ginger Oleoresin Production in Nigeria for Economic Growth and Sustainable Supply to User Industries
}

\author{
Ifeyinwa C. Olife* \\ Agriculture and Agro-Allied Department, Raw Materials Research and Development Council, Abuja, Nigeria \\ Abubakar H. Mohammed \\ Finance and Accounts Department, Raw Materials Research and Development Council, Abuja, Nigeria \\ Hussaini D. Ibrahim \\ Director-General, Raw Materials Research and Development Council, Abuja, Nigeria
}

\begin{abstract}
Nigeria ranks $2^{\text {nd }}$ amongst top 10 ginger producers in the world with a production of 691,239 tonnes and its ginger is among the best, with its aroma, pungency and high oil and oleoresin content as distinct features. The most important form of ginger commercially is the dried form because it can be further processed in the industry to ginger powder, ginger oil and ginger oleoresin. There is an increasing international demand for ginger oleoresins, especially for the production of alcoholic beverages, ginger ale and gingerbread. The global ginger oil market is expected to grow at a CAGR of $9.41 \%$ from 2020 to 2025 to reach a total market size of US\$189.431 million by 2025, increasing from US\$110.435 million. Nigeria, with the volume of ginger production and distinctive features of its ginger, should tap into this market demand. However, ginger is exported from Nigeria in the split-dried form while value-added products such as ginger powder, essential oils and oleoresin are imported at high cost. According to the Nigeria Customs Service data, 700,891 $\mathrm{kg}$ of resinoids and mixtures of odoriferous substances were imported to Nigeria from 2016 to 2019 at a value of 1.24 billion. To take advantage of the ever expanding global oleoresin market, formation of farmers clusters/cooperatives, development of farmers-processors linkages, quality assurance through Good Agricultural Practices, technology development, Public-Private Partnerships, development of Nigeria Industrial Standards (NIS) for oleoresins and import restrictions on ginger oleoresin are recommended. There is need for synergy amongst government agencies to harmonize and integrate various development plans and strategies for ginger value chain. Establishment of an institutional framework for proper coordination is also recommended to harmonize all the activities in the sector for greater impact.
\end{abstract}

Keywords: Ginger, value addition, oleoresin, resinoids, ginger oil, export, import

DOI: $10.7176 / \mathrm{JNSR} / 12-22-03$

Publication date: November $30^{\text {th }} 2021$

\section{Introduction}

Oleoresins are semi-solid extracts, from spices and herbs, composed of resin and essential or fatty oil. Oleoresin is oil and resin that is a mixture of essential oils as an aroma carrier and a kind of resin as a carrier of flavour (Seema, et al., 2016; Susheela, 2000). They are naturally occurring mixture of essential oil and a resin extracted from various spices with organic solvents (Moyler, 1991). Oleoresins are characterised by high potency of active components which enables their usage in small dosages and they find applications in Beverages, Meat Canning, Confectionery, Sauces and Pharmaceuticals. They are also used as a base for a number of seasonings. Oleoresins are increasingly used in pharmaceutical applications owing to its antioxidant and anti-inflammatory properties. The type of solvent affects the quality and quantity of oleoresin obtained (Said et al., 2015).

Oleoresins can be produced from various plant sources and from different plant parts. The plants include basil, capsicum annum (paprika/pepper), cardamom, celery seed, cinnamon bark, clove bud, fenugreek, fir balsam, ginger, garlic, onion, mace, nutmeg, parsley, pepper (black/white), rosemary, sage, savory, thyme, turmeric, vanilla, bay leaves, etc. while plant parts include leaves, stems, bark, seeds, fruits, roots and plant exudates. Oleoresins can replace whole/ground spices without impairing any flavour and aroma characteristic (Burdock, 2010; UNIDO \& FAO, 2005).

Oleoresins provide a number of advantages over traditional spices as flavouring agents. They represent the complete flavour and non-volatile resinous fraction present in the spices (Sharma Sharma, 2004). Important flavour compounds found in culinary herbs and other spice plants include eugenol from allspice, cinnamon, cassia, clove; piperine from black pepper; gingerol from ginger; myristicin from nutmeg; turmerone from turmeric and vanillin from vanilla (Peter, 2000). Oleoresins are 5-20 times stronger in flavour than their corresponding spices and they are commonly marketed as spice drops (Ravindran and Kallupurackal, 2012; Suderman, 2011 ). Oleoresin market by segment is shown in Table 1. 
Table 1: Oleoresin Market by Segment

\begin{tabular}{|l|l|l|l|l|}
\hline Source & $\begin{array}{l}\text { By Raw } \\
\text { Material }\end{array}$ & Application & Extraction Process & Region \\
\hline Paprika & Leaves & Food \& Beverages & Solvent Extraction & North America \\
\hline Capsicum & Seeds & $\begin{array}{l}\text { Pharmaceutical \& } \\
\text { Nutraceutical }\end{array}$ & $\begin{array}{l}\text { Supercritical fluid } \\
\text { extraction }\end{array}$ & Europe \\
\hline Seed spices & Flowers & Flavours \& Colour & & Asia Pacific \\
\hline Turmeric & Roots & $\begin{array}{l}\text { Personal care } \\
\text { products }\end{array}$ & $\begin{array}{l}\text { Central \& South } \\
\text { America }\end{array}$ \\
\hline Herbs & Feed & $\begin{array}{l}\text { Middle East \& } \\
\text { Africa }\end{array}$ \\
\hline Ginger & Stems & Others & & \\
\hline Cinnamon \& Cassia & Fruits & & & \\
\hline Herbs & Plant exudates & & & \\
\hline $\begin{array}{l}\text { Others (cardamom, floral, } \\
\text { vanilla, tamarind, nutmeg, } \\
\text { onion, and garlic) }\end{array}$ & & & & \\
\hline
\end{tabular}

According to MarketsandMarkets (2019), the global oleoresins market is estimated to be valued at USD 1.2 billion in 2019 and is projected to reach USD 1.7 billion by 2025, recording a CAGR of 6.0\% from 2019 to 2025. The rising trend of using natural flavors in processed food and an increasing number of quick service restaurants have led to a surge in demand for oleoresins. Among the different applications, the market is estimated to be dominated by the food \& beverages segment from 2019 to 2025, owing to the wide usage of oleoresins that provide a natural flavor and fragrance in confectioneries and beverages.

\section{Ginger and Oleoresin}

\subsection{Ginger rhizome}

Ginger has a slightly biting and hot note; its aroma is rich, sweet, warm with a distinctive woody olfactory note. Nigeria is the third-largest producer of ginger in the world (after India and China). The estimated global production shares for the top three ginger producing countries in the world are $35 \%, 18 \%$ and $11.5 \%$ for India, China and Nigeria respectively (OEC, 2019).

According to FAOSTAT, top ginger exporters in 2018 were China, Thailand, Netherlands, Peru and Nigeria China had $55 \%$ market share worth USD 525 million, Thailand with $8.95 \%$ market share worth USD 83.8 million, Netherlands with $7.7 \%$ market share worth USD 72.8 million, Peru with $4.95 \%$ market share worth USD 46.6 million and Nigeria with $3.98 \%$ market share worth USD 37.4 million. Also, top ginger importers in 2018 were the United States of America (USD 114 million), Pakistan (USD 107 million USD 107 million), Japan (USD 79.2 million) and Germany (USD 55.7 million) (OEC, 2019). Other major importing countries are the United Kingdom, Saudi Arabia, Singapore, Malaysia, Korea, the Netherlands, Canada and France.

Worldwide ginger production in 2019 reached 4 million tonnes with a planted area of 385,000 hectares. The Asia continent topped the chart with production of 3.2 million tonnes, followed by Africa with about 811,000 tonnes, America with 37,000 tonnes and Oceanic with about 9,000 tonnes (FAO, 2021). Global Ginger Market is expected to reach US\$ 8.46 Billion by the end of the year 2027 from US\$ 6.82 Billion in 2020, growing with a CAGR of 3.13\% from 2021 to 2027 (Research and Markets, 2021). According to FAOSTAT (2021), Nigeria ranked $2^{\text {nd }}$ amongst the top 10 ginger producers in the world with a production of 691,239 tonnes (Table 2 ).

Table 2: Top 10 Ginger producing countries in 2019

\begin{tabular}{|l|l|l|}
\hline Rank & Country & Production (Tonnes) \\
\hline 1 & India & $1,788,000$ \\
\hline 2 & Nigeria & 691,239 \\
\hline 3 & China & 581,137 \\
\hline 4 & Nepal & 297,512 \\
\hline 5 & Indonesia & 174,380 \\
\hline 6 & Thailand & 166,923 \\
\hline 7 & Cameroon & 83,434 \\
\hline 8 & Bangladesh & 80,234 \\
\hline 9 & Japan & 45,506 \\
\hline 10 & Philippines & 26,929 \\
\hline
\end{tabular}

Source: FAOSTAT, 2021

At the international market, ginger is presented in three major forms namely; fresh or green ginger, 
preserved ginger and dried (split and whole). The most important form of ginger commercially is the dried one because it can be further processed in the industry to ginger powder, ginger oil and ginger oleoresin. For a good yield of oleoresin and ginger oil, ginger should be harvested at $7-8$ months after planting (Kausha, et al., 2017). Ginger based products have wide range applications in many industries like food and beverage, pharmaceutical and cosmetics, confectionery, tobacco processing, etc. There is also increasing demand for ginger tea and ginger health drinks. Nigeria's ginger is among the best in the world, with its aroma, pungency and high oil and oleoresin content as distinct features (Njoku et al., 1995). The main producing zone is Kaduna state, and to a lesser extent Nasarawa, Niger, Gombe, Bauchi, and Benue (Okafor, 2002).

\subsection{Ginger Oleoresin}

Ginger Oleoresin is a dark red-brown, viscous material with a natural, unique ginger aroma. Commercial ginger oleoresin usually has a volatile oil content of 25-30\% and replacement strength of $1 \mathrm{~kg}$ oleoresin for $28 \mathrm{~kg}$ good-quality ground spice (Vasala, 2012). There is an increasing international demand for ginger oleoresins, especially for the production of alcoholic beverages, ginger ale and gingerbread. It is also used in sweets, curry powders, soft drinks, sauces and it is in huge demand in the Ayurvedic, nutraceutical and pharmaceutical industries. The global ginger oil market is expected to grow at a CAGR of 9.41\% from 2020 to 2025 to reach a total market size of US\$189.431 million by 2025, increasing from US\$110.435 million (Research and Markets, 2020). Nigeria, with the volume of ginger production and distinctive features of its ginger, could tap into this global market demand.

However, the level of value addition to ginger in Nigeria is very low. Ginger is exported from Nigeria in the split-dried form while value-added products such as ginger powder, essential oils and oleoresin are imported at high cost. According to Nigeria Customs Service data, $700,891 \mathrm{~kg}$ of resinoids and mixtures of odoriferous substances were imported to Nigeria from 2016 to 2019 at a value of 1.24 billion Naira (Table 3).

Table 3: Resinoids and Mixtures of Odoriferous Substances Imports to Nigeria, 2016 - 2019

\begin{tabular}{|c|c|c|c|c|c|c|c|c|c|c|c|}
\hline \multirow[b]{2}{*}{ HS CODE } & \multirow[t]{2}{*}{ Description } & \multicolumn{2}{|l|}{2016} & \multicolumn{2}{|l|}{2017} & \multicolumn{2}{|l|}{2018} & \multicolumn{2}{|l|}{2019} & \multicolumn{2}{|c|}{ Total $(2016-2019)$} \\
\hline & & $\begin{array}{l}\text { Qty } \\
\text { (kg) }\end{array}$ & Value (\$) & $\begin{array}{l}\text { Qty } \\
(\mathrm{kg})\end{array}$ & Value (\$) & $\begin{array}{l}\text { Qty } \\
(\mathrm{kg})\end{array}$ & Value (\$) & $\begin{array}{l}\text { Qty } \\
(\mathrm{kg})\end{array}$ & Value (\$) & $\begin{array}{l}\text { Qty } \\
(\mathrm{kg})\end{array}$ & Value ( \\
\hline 3301300000 & Resinoids & 17,848 & $6,051,641$ & 4,787 & $11,316,475$ & 2,575 & $7,499,690$ & 2,607 & $8,131,327$ & 27,816 & $32,999,133$ \\
\hline \multirow{3}{*}{3302100000} & $\begin{array}{l}\text { Mixtures of } \\
\text { odoriferous substances } \\
\text { of a kind }\end{array}$ & 34,626 & $122,168,656$ & 31,533 & $106,697,798$ & 36,950 & $76,842,424$ & NA & NA & 103,109 & $305,708,878$ \\
\hline & $\begin{array}{l}\text { Mixtures of } \\
\text { odoriferous substances } \\
\text { of a kind used in the } \\
\text { food or drink } \\
\text { industries }\end{array}$ & NA & NA & NA & NA & 32,862 & $104,525,699$ & 91,011 & $110,968,553$ & 123,872 & $215,494,251$ \\
\hline & $\begin{array}{l}\text { Mixtures of,or with } \\
\text { basis of,odoriferous }\end{array}$ & 37,808 & $28,728,052$ & 29,537 & $99,805,227$ & 140,318 & $46,282,046$ & NA & NA & 207,664 & $174,815,324$ \\
\hline \multirow{3}{*}{3302901000} & $\begin{array}{l}\text { Mixtures of } \\
\text { odoriferous substances } \\
\text { of a kind }\end{array}$ & 14,980 & $19,544,767$ & 9,529 & $15,837,497$ & 12,192 & $18,499,578$ & NA & NA & 36,701 & $53,881,842$ \\
\hline & $\begin{array}{l}\text { Mixtures } \\
\text { odoriferous substances } \\
\text { of a kind used in } \\
\text { perfumery }\end{array}$ & NA & NA & NA & NA & 6,505 & $12,654,358$ & 15,654 & $15,741,099$ & 22,158 & $28,395,457$ \\
\hline & $\begin{array}{l}\text { Mixtures of,or with a } \\
\text { basis of,odoriferous }\end{array}$ & 40,445 & $28,642,249$ & 16,191 & $71,491,715$ & 16,920 & $5,044,968$ & NA & NA & 73,556 & $105,178,932$ \\
\hline \multirow{4}{*}{3302909000} & $\begin{array}{l}\text { Mixtures of } \\
\text { odoriferous substances } \\
\text { of a kind }\end{array}$ & 19,584 & $44,050,093$ & 10,554 & $38,945,828$ & 12,950 & $42,747,659$ & NA & NA & 43,089 & $125,743,581$ \\
\hline & $\begin{array}{l}\text { Mixtures of } \\
\text { odoriferous substances } \\
\text { of a kind used in other } \\
\text { industries }\end{array}$ & NA & NA & NA & NA & 8,176 & $31,722,025$ & 9,389 & $45,024,044$ & 17,565 & $76,746,069$ \\
\hline & $\begin{array}{l}\text { Mixtures of,or with a } \\
\text { basis of,odoriferous }\end{array}$ & 14,161 & $41,027,445$ & 13,127 & $33,774,174$ & 18,072 & $49,484,930$ & $\mathrm{NA}$ & NA & 45,360 & $124,286,548$ \\
\hline & Grand Total & 179,454 & $290,212,903$ & 115,257 & $377,868,714$ & 287,520 & $395,303,376$ & 118,660 & $179,865,023$ & 700,891 & $1,243,250,015$ \\
\hline
\end{tabular}

Source: Nigeria Customs Service, 2020

Import volume and value of Resinoids and Mixtures of odoriferous substances by year are shown in Figures 1 and 2 respectively. The highest volume of $287,520 \mathrm{~kg}$ worth over 395.303 million was recorded in 2018 . The lowest volume of $115,257 \mathrm{~kg}$ in 2017 was worth over $\$ 377.869$ million, import volume peaked in 2018 before dropping to $118,600 \mathrm{~kg}$ in 2019 at the cost of over 179.865 million. 


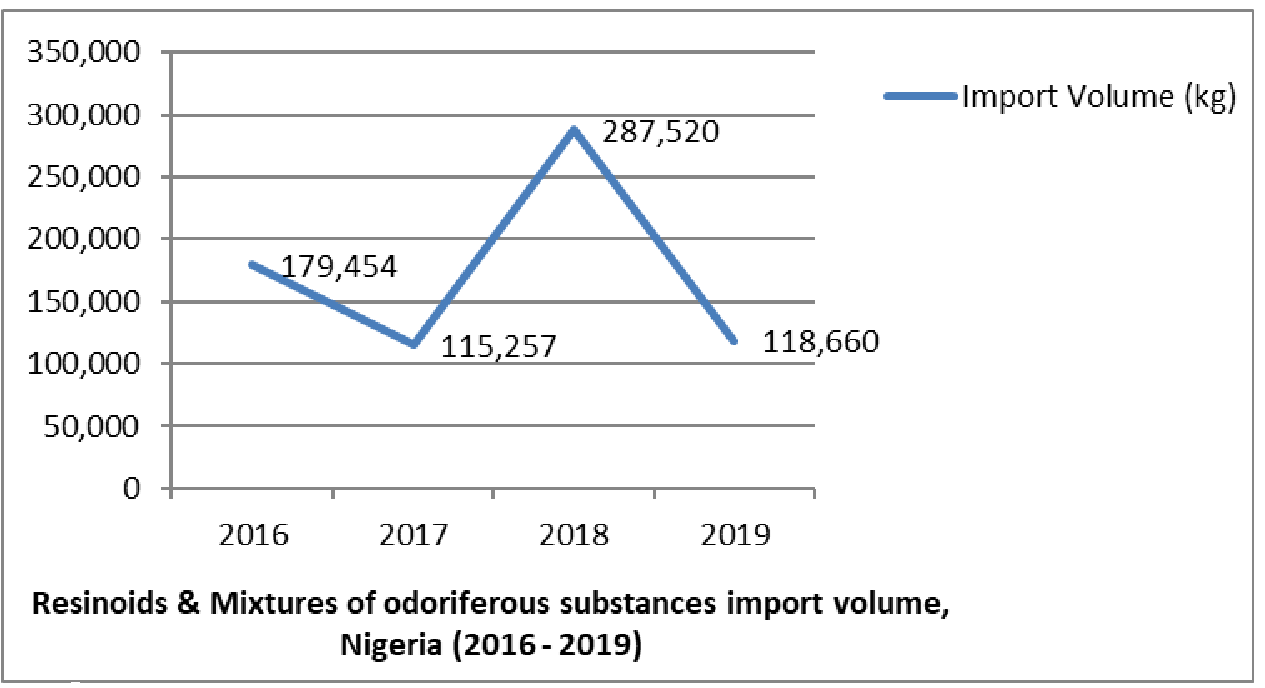

Figure 1: Resinoids and Mixtures of odoriferous substances import volume, Nigeria (2016 - 2019)

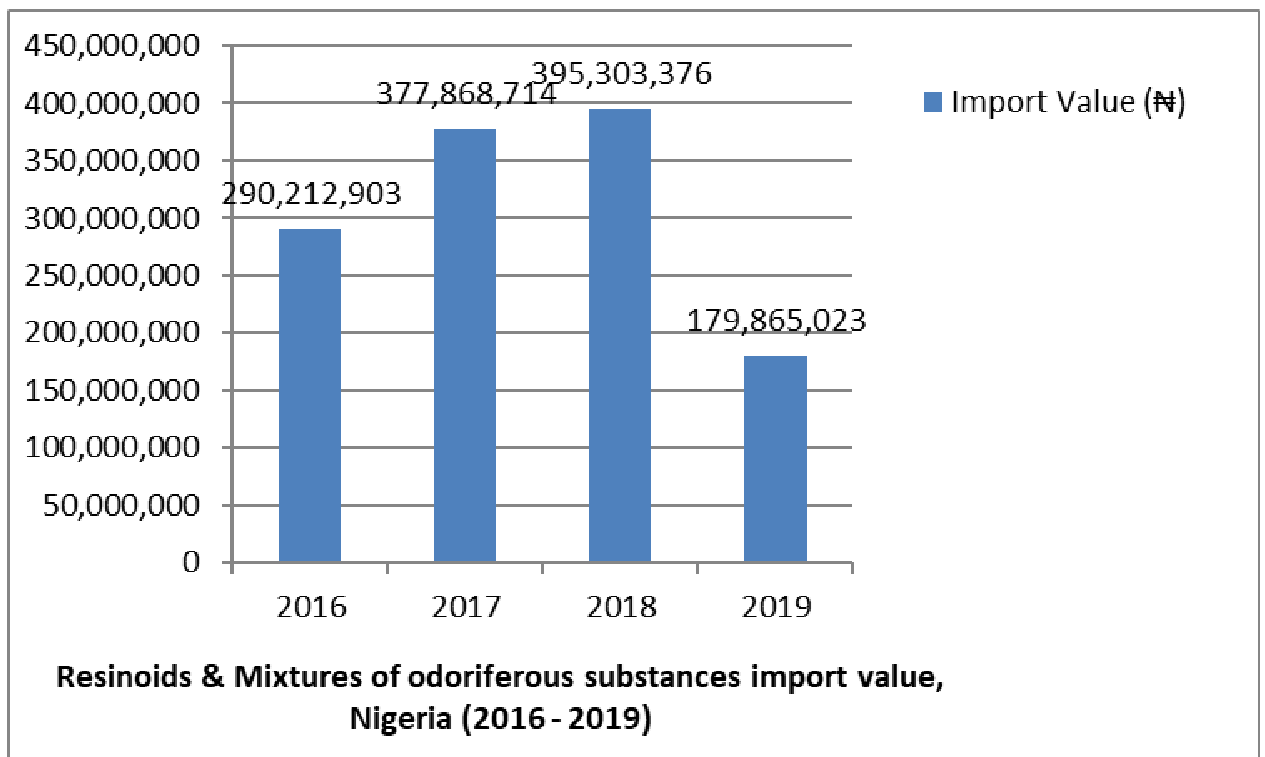

Figure 2: Resinoids and Mixtures of odoriferous substances import value, Nigeria (2016 - 2019)

\section{RMRDC's INITIATIVES ON GINGER VALUE CHAIN DEVELOPMENT IN NIGERIA}

Recognizing the economic potentials of ginger and the need to position ginger as one of the key economic crops in Nigeria, the Raw Materials Research and Development Council (RMRDC) organized a Stakeholders' Forum on Ginger Value Chain Development in Nigeria geared towards bringing together key players in the ginger value chain to brainstorm on the status, challenges, options, opportunities and policy requirements in the sector.

The Council identified and collaborated with Belphins Nigeria Ltd, Kafanchan, Kaduna State and Tiger Foods Ltd, Onitsha, Anambra State on production of ginger oleoresin and ginger value-added products respectively. In the course of collaborations, physico-chemical analysis and microbiological examinations were carried out on samples of oleoresin produced by Belphins Nigeria Ltd at the Institute of Public Analysts of Nigeria (IPAN) and the National Agency for Food and Drug Administration and Control (NAFDAC) using the methods of Association of Official Analytical Chemists (AOAC). Figure 3 shows samples of ginger oleoresin produced by Belphins Nigeria Ltd, Kafanchan, Kaduna State. 


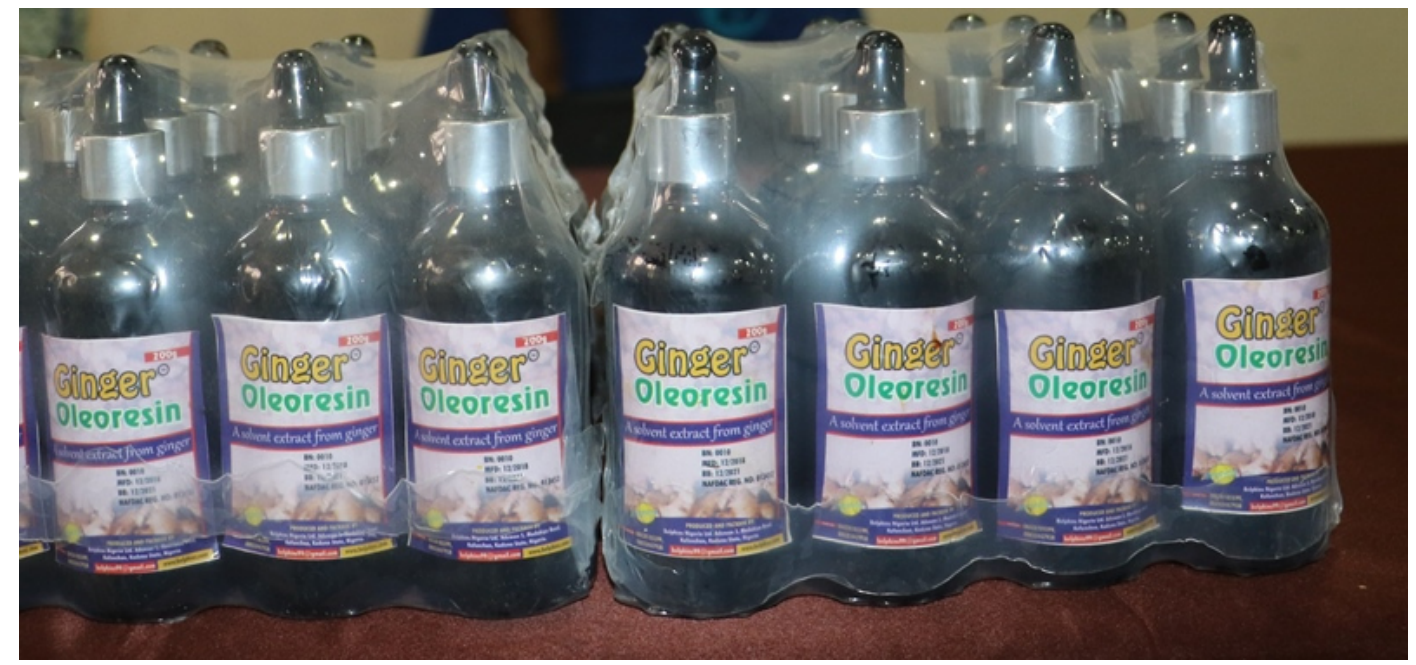

Figure 3: Samples of Ginger Oleoresin

Courtesy: Belphins Nigeria Ltd, Kaduna

The outcome of the analyses (Tables 4 and 5) formed the basis for a roundtable/advocacy meeting with the Organised Private Sector (OPS) for the utilisation of made-in-Nigeria ginger oleoresin by Nigeria's industries.

Table 4: Physico-Chemical Analysis and Microbiological Examinations of Ginger Oleoresin Sample 1

\begin{tabular}{|l|l|l|}
\hline Physico-Chemical Analysis & Results & Limits \\
\hline General Description (Appearance) & Dark-brown viscous oil & NA \\
\hline Odour & Nil & NA \\
\hline Relative density at $20^{\circ} \mathrm{C}$ & 1.055 & NA \\
\hline Volatile matter $105^{\circ} \mathrm{C}(\%)$ & 13.62 & NA \\
\hline Saponification value & 87.69 & NA \\
\hline Acid value (mg KOH/g) & 26.67 & NA \\
\hline Iodine value & 37.01 & NA \\
\hline Mineral oil & - & NA \\
\hline Free fatty acid (as oleic) $\%$ & 13.27 & NA \\
\hline Ash (\%) & - & NA \\
\hline & & \\
\hline Microbiological Exams & & \\
\hline Total Aerobic Mesophilic Count (cfu/g) & Nil & 1000 max \\
\hline Total Coliform & Nil & 10 max \\
\hline Yeast/Moulds (cfu/g) & Nil & $100 \mathrm{max}$ \\
\hline E. coli & Absent & $0 \mathrm{~g}, 0(\mathrm{cfu} / \mathrm{g})$ \\
\hline Salmonella spp & Absent & \\
\hline & & \\
\hline Pesticide Residues (ppb) & Not detected & \\
\hline
\end{tabular}


Table 5: Physico-Chemical Analysis and Microbiological Examinations of Ginger Oleoresin Sample 2

\begin{tabular}{|c|c|c|}
\hline Physico-Chemical Analysis & Results & Expected \\
\hline General Description (Appearance) & $\begin{array}{ll}\text { Black } & \text { viscous } \\
\text { liquid } & \end{array}$ & $\mathrm{NA}$ \\
\hline Odour & Unobjectionable & NA \\
\hline Relative density at $20^{\circ} \mathrm{C}$ & - & NA \\
\hline Volatile matter $105^{\circ} \mathrm{C}(\%)$ & 10.65 & NA \\
\hline Saponification value & - & NA \\
\hline Acid value (mg KOH/g) & 7.57 & NA \\
\hline Iodine value & - & NA \\
\hline Mineral oil & Negative & NA \\
\hline Free fatty acid (as oleic) $\%$ & - & NA \\
\hline $\operatorname{Ash}(\%)$ & 4.74 & NA \\
\hline Vitamins (mg/l) & & Recommended daily dose (RDM) \\
\hline $\mathrm{B}_{3}$ (Niacin) & Not detected & $13-17 \mathrm{mg}$ \\
\hline $\mathrm{B}_{2}$ (Riboflavin) & 1.3 & $1.2-1.6 \mathrm{mg}$ \\
\hline $\mathrm{B}_{1}$ (Thiamin) & 6.5 & $1.0-1.5 \mathrm{mg}$ \\
\hline $\mathrm{B}_{6}$ (Pyridoxine) & 0.2 & $1.2-1.8 \mathrm{mg}$ \\
\hline $\mathrm{B}_{12}$ (Cobalamin) & 5.5 & $3 \mu \mathrm{g}$ \\
\hline $\mathrm{C}$ & Not detected & \\
\hline \multicolumn{3}{|l|}{ Trace Elements/Minerals (ppm) } \\
\hline Arsenic & 0.231 & Tolerable dietary intake $130 \mu \mathrm{g} /$ day $(\max )$ \\
\hline Cadmium & 0.016 & Permissible level $0.1 \mathrm{mg} / \mathrm{kg}$ \\
\hline Chromium & 0.035 & $25-35 \mu \mathrm{g}$ \\
\hline Mercury & 0.085 & $\begin{array}{l}\text { Tolerable weekly intake/ safe level } 4 \mu \mathrm{g} / \mathrm{kg} \text { body } \\
\text { weight }\end{array}$ \\
\hline Manganese & 0.001 & $\begin{array}{l}\text { Recommended daily allowance (RDA) } 1.8- \\
2.3 \mathrm{mg}\end{array}$ \\
\hline Iron & 0.02 & RDA $40-45 \mathrm{mg}$ \\
\hline Lead & 0.012 & $0.3 \mathrm{mg} / \mathrm{kg} \max$ \\
\hline \multicolumn{3}{|l|}{ Microbiological Exams } \\
\hline $\begin{array}{l}\text { Total Aerobic Mesophilic Count } \\
(\mathrm{cfu} / \mathrm{g})\end{array}$ & $<1 \times 10^{3}$ & $1000 \max$ \\
\hline Total Coliform & Nil & $10 \max$ \\
\hline Yeast/Moulds (cfu/g) & $1.0 \times 10^{1}$ & $100 \max$ \\
\hline E. coli & 0 & $0 \mathrm{~g}, 0(\mathrm{cfu} / \mathrm{g})$ \\
\hline Salmonella spp & - & \\
\hline
\end{tabular}

Also, ginger splitting machine and ginger drying equipment were designed and developed in collaboration with the National Root Crops Research Institute (NRCRI), Umudike, Abia State and Farm Industries, Owerri, Imo State. The machines were deployed to Ginger Growers Association in Mbaitoli Local Government Area of Imo Sate for commercial ginger processing.

Improved varieties of ginger rhizomes (UG2) have been distributed to Ginger Farmers Association in selected States of Nigeria to promote cultivation and increase yield.

\section{CONCLUSION AND RECOMMENDATIONS}

\subsection{Recommendations}

The demand for ginger oleoresin in Nigeria is on the rise from both food and Pharmaceutical industries but current demand is not being met locally, leading to import dependence. Nigeria's ginger is among the best in the world, with its aroma, pungency and high oil and oleoresin content as distinct features. Therefore, the country has huge potentials for oleoresin production and marketing. To take advantage of the ever expanding global oleoresin market, the following strategies are recommended.

- Formation of Clusters/Cooperatives: Farmers should be encouraged to form clusters/cooperatives for easier access to funds, improved crops varieties and other farm inputs from the government and development agencies. 
- Farmers-Processors Linkages: There should be linkages between farmers and processors for the offtake of the commodity at agreed price to mitigate harvest risk. The overall goal is to get more farmers involved in the cultivation of ginger for sustainable supply of raw materials to existing and emerging oleoresin extraction plants.

- Quality Assurance: Farmers should be trained on ginger Good Agricultural Practices (GAP) to guarantee quality commodity for processing.

- Technology Development: Existing technologies for small scale oleoresin extraction should be adopted and copied through reverse engineering.

- Public-Private Partnerships: Business linkages between public and private sectors for the establishment of small scale oleoresin extraction plants across the country should be facilitated and developed by agencies like RMRDC and NRCRI.

- Standards: Nigeria Industrial Standards (NIS) for oleoresins should be developed by the Standards Organization of Nigeria (SON) in collaboration with other stakeholders to build user industry's trust.

Tariff: Oleoresin import should be discouraged through tariff and other measures to encourage local production.

\subsection{Conclusion}

The global Ginger Oleoresin market is anticipated to rise at a considerable rate between 2021 and 2026. Despite the fact that Nigeria has competitive advantage in the production of ginger for oleoresin extraction, the country still depends on importation of oleoresin for industrial use. Therefore, there is need for synergy amongst government agencies to harmonize and integrate various development plans and strategies for the growth of the sector. An institutional framework should be established for proper coordination. Also, the right incentives for investment in the oleoresin sector should be created while the existing ones should be implemented judiciously to attract investors to the sector. The production of ginger oleoresin in Nigeria would undoubtedly create more value for the commodity in the industry and enhance its economic potentials.

\section{REFERENCES}

Burdock, G.A. (2010), Fenaroli's Handbook of Flavor Ingredients (6th ed.), Taylor \& Francis, ISBN 978-14200-9077-2

FAO (2021). Production of Ginger: Top 10 Producers 2019. http://www.fao.org/faostat/en/\#data

FAO (2021). Production Share of Ginger by Region 2019. http://www.fao.org/faostat/en/\#data

Kaushal, M., Gupta, A., Vaidya, D. and Gupta, M. (2017). Postharvest Management and Value Addition of Ginger (Zingiber Officinale Roscoe): A Review. International Journal of Environment, Agriculture and Biotechnology, 2(1), pp397-412

MarketsandMarkets (2019). Oleoresins Market. Report Code: FB 7281

Moyler DA. (1991). Oleoresins, Tinctures and Extracts. In: Ashurst PR, editor. Food flavourings. Glasgow: Blackie.

Njoku B.O, Mbanaso E.N.A. and Asumugha G.N. (1995). Ginger Production by Conventional and Tissue Culture Techniques. Dolf Madi Publishers, Owerri. pp13-14

OEC (2019). Ginger Trade. https://legacy.oec.world/en/profile/hs92/091010/\#Exporters

Okafor, G. I. (2002). Processing and Utilization of Ginger: Effect of Processing Methods on Product Quality, and its Application in Fruit and Bakery Products. TWAS-CSRI postdoctoral fellowship research report, CFTRI, India. p32.

Peter, K.V. (2000). Introduction. In: Handbook of Herbs and Spices (Peter, K.V. eds.). Woodhead Publishing Ltd, Cambridge, England. Pp1-12.

Ravindran, P.N. and Kallupurackal, J.A. (2012). Chapter 6 - Black Pepper. In: Handbook of Herbs and Spices Volume 1 (2nd Edition, K.V. Peter, eds). Woodhead Publishing Ltd, Cambridge, England. pp 86-115.

Research and Markets (2020). Ginger Oil Market - Forecasts from 2020 to 2025. ID: 5215214. http://www.researchandmarkets.com

Research and Markets (2021). The "Global Ginger Market \& Volume By Production, Import, Export, Application, Company Analysis, Forecast". http://www.researchandmarkets.com

Said, P.P., Arya, O.P., Pradhan, R.C., Singh, R.S. and Rai, B.N. (2015). Separation of Oleoresin from Ginger Rhizome Powder Using Green Processing Technologies. J Food Process Eng. 38:107-114.

Seema R, Hindole G, and Muddasir B. (2016). Phytochemical Characterization and Antioxidative Property of Ocimum canum: Effect of Ethanolic Extract of Leaves and Seeds on Basic Immunologic and Metabolic Status of Male Rats. Immuno Biol. Vol. 1. No. 2.

Sharma, M.M. and Sharma, R.K.(2004). Chapter 12 Coriander. In: Handbook of Herbs and Spices Volume 2 (2 ${ }^{\text {nd }}$ Edition, K.V. Peter, eds). Woodhead Publishing Ltd, Cambridge, England. p216-249.

Susheela R.U. (2000). Handbook of Spices, Seasonings and Flavoring. Lancaster-USA: Techonomic Publishing 
Co. Inc.

Suderman, D.R. (2011). Chapter 5 - Effective Use of Flavorings and Seasonings in Batter and Breading Systems. In: American Associate of Cereal Chemists International, Batters and Breadings in Food Processing $\left(2^{\text {nd }}\right.$ Edition, Karel Kulp, Robert Loewe, Klaus Lorenz, Janette Gelroth eds.), AACC International Press. p73-90

UNIDO \& FAO (2005). Herbs, Spices and Essential Oils: Post-harvest Operations in Developing Countries. http://www.fao.org

Vasala, P.A. (2012). Chapter 18 - Ginger. In: Woodhead Publishing Series in Food Science, Technology and Nutrition, Handbook of Herbs and Spices (Second Edition). (Peter, K.V. eds.). Woodhead Publishing Ltd, Cambridge, England. p319-335.

\section{ACKNOWLEDGEMENT}

The authors are grateful to Belphins Nigeria Ltd, Kafanchan, Kaduna State and Tiger Foods Ltd, Onitsha, Anambra State for collaborations on ginger development in Nigeria. We are also grateful to the Institute of Public Analysts of Nigeria (IPAN) and the National Agency for Food and Drug Administration and Control (NAFDAC) for analysing the samples in their laboratories. 